\author{
P.В. Деніна
}

\title{
ІНФАРКТ МІОКАРДА ПРИ ВАГІТНОСТІ: ВИПАДОК 3 ПРАКТИКИ
}

ДВНЗ «Івано-Франківський національний медичний університет»

Резюме. Серцево-судинні захворювання, як і раніше, залишаються однією з головних причин материнської смертності в розвинених країнах. Найбільш поширеними проблемами, що ускладнюють вагітність, є ожиріння, порушення ліпідного обміну, цукровий діабет (ЦД), артеріальная гіпертензія (АГ), куріння.

Розвиток інфаркту міокарда у вагітної на сьогодні досить рідкісна ситуація. Однак в останні роки спосте-

Вступ. До останнього часу вважали, що ішемічна хвороба серця (IXC) є хворобою чоловіків середнього та літнього віку, у зв'язку з чим більшість широкомасштабних досліджень проводили в чоловічій когорті. Тому націленість лікарів на виявлення IXC у жінок досить занижена, що сприяє гіподіагностиці даної патології в жіночій популяції. У цілому в жінок IXC виникає на 1015 років пізніше, ніж у чоловіків. Тому у зв'язку зі збільшенням тривалості життя населення IXC стає дедалі більш характерною і для жінок. Враховуючи також загальне постаріння населення, на сьогодні IXC $\epsilon$ найбільш важливою причиною смертності та інвалідності серед жінок старшого віку, значно перевищуючи ці показники при раку молочної залози $[1,2,8]$.

У пацієнток з IXC відзначають суттєві відмінності в клінічній картині захворювання і певні особливості діагностики. До того ж рекомендації щодо лікування IXC одержані переважно для хворих чоловічої статі і не до кінця відомо, чи можна отримані дані екстраполювати на жіночу популяцію.

Проблемою залишається розвиток IXC, зокрема інфаркту міокарда (IM) у вагітних.

Етіологічні фактори IM у вагітних мало відрізняються від таких у загальній популяції (куріння, атеросклероз, ожиріння, артеріальна гіпертензія, цукровий діабет). Проте їх вплив може бути посилено станом гіперкоагуляції при вагітності.

IM у вагітної вперше був описаний H. Katz y 1922 році [7]. В останні десятиліття частота IM досягала від 3 до 10 випадків на 100000 пологів [4,5]. Причому за період з 1991 по 2003 роки його поширеність зросла в п'ять разів - 31,3 до 6,2 на 100 тис. вагітних [3]. Найчастіше IM реєструється в допологовому періоді або під час пологів (59\%), рідше (41\%) - після них [9].

Поширеність IM при вагітності складала у 2003 році 6,2 випадка на 100 тис. пологів, смертність від IM - 0,35 на 100 тис. пологів [9]. Часто- рігається значне збільшення частоти факторів ризику серцево-судинних захворювань у вагітних, збільшується вік жінок, що планують вагітність. У статті представлено клінічний випадок із практики, а саме розвиток інфаркту міокарда у вагітної із супутнім цукровим діабетом.

Ключові слова: інфаркт міокарда, вагітність, клінічний випадок, діагностика, лікування.

та гострого коронарного синдрому (ГКС) під час вагітності оцінюється на рівні 1:10000 вагітностей $[8,9]$.

За даними А. James і співавт. (2006), у пацієнток 20-25 років ризик розвитку IM у 30 разів нижче, ніж у жінок старше 40 років і становить понад 30 випадків проти 1 на 100 тис. пологів.

Ішемія міокарда під час вагітності може імітувати скарги, характерні для вагітності. Таким чином, діагноз IM часто упускається під час вагітності.

Зміни гемодинаміки, гемостазу та гормональної перебудови під час вагітності та в післяпологовому періоді створюють тло для розвитку IM.

Основними причинами розвитку IM більшість дослідників вважають гормональну перебудову організму, збільшення об'єму крові в гемоциркуляції та інші фізіологічні зміни, які відбуваються в період вагітності. При цьому атеросклероз як причина IM спостерігається лише у 1/3 вагітних.

Високий ризик IM спостерігається у вагітних 3 антифосфоліпідним синдромом, спадковими тромбофіліями; гіперкоагуляцією в поєднанні 3 генетично-зумовленою схильністю до тромбозів, що призводить до тяжких тромботичних ускладнень, враховуючи IM [13].

Є достатня доказова база того, що IM при вагітності має ряд особливостей. Його діагностика і диференційна діагностика вкрай складні. Симптоми IM, такі, як задишка, тахікардія, дискомфорт у ділянці серця, можуть спостерігатися при нормальном перебігу вагітності в результаті призначення терапії $\beta$-адреноміметиками і сульфатом магнію [12].

У діагностиці IM важливу роль відіграє визначення серцевих тропонінів I і T і МВ фракції креатинінфосфокінази (МВ КФК). Однак у вагітних останній метод не $є$ інформативним, оскільки підвищення рівня МВ КФК може спостерігатися і при нормальному перебігу вагітності, а також під 
час пологів і в ранньому післяпологовому періоді. Тільки визначення тропоніну $є$ золотим стандартом діагностики IM при вагітності [10]. Найбільшою проблемою у таких випадках є підбір адекватної терапії. У загальній популяції черезшкірне коронарне втручання (ЧКВ) $є$ стратегією вибору при IM з елевацією сегмента ST. Тим не менш, ЧКВ під час вагітності передбачає вплив на плід високих рівнів радіації порівняно 3 діагностичною ангіографією. Високі дози випромінювання є ризиком спонтанного аборту, деформації органів плода, розумової відсталості і розвитку раку в дітей.

Доза опромінення під час рентгенографії грудної клітки для плода повинна мати середню експозицію $0,02 \mathrm{mSv}$, а максимальну $0,1 \mathrm{mSv}$ у складних ЧКВ (Національна рада 3 радіаційного захисту та вимірювань 1998) [1].

Доступ через променеву артерію зводить променеве навантаження на плід до мінімуму. ЧКВ під час вагітності можна вважати відносно безпечним, враховуючи мінімальне променеве навантаження. Тим не менше, до завершення основного органогенезу (до 15 тижнів) опромінення, по можливості, слід уникати. Дози, що перевищують 50-100 mSv збільшують частоту вад розвитку плода.

Також IM при вагітності може ускладнюватися набряком легень - однією з головних причин смерті при IM. Однак при вагітності існує багато інших чинників розвитку набряку: прееклампсія, емболія навколоплідними водами, септичний шок, масивна інфузійна терапія [14].

Лікування IM включає консервативні методи та активну тактику із застосуванням різних кардіохірургічних технологій. Можливість тромболізу при вагітності залишається дискутабельним питанням. Відомо, що в експериментах на тваринах стрептокіназа і тканинний активатор плазміногена не проникають через плаценту. Однак під час вагітності особливо небезпечні тромболітичні ускладнення такої терапії: спонтанні аборти, вагінальні і маткові кровотечі, передчасне відшарування плаценти $[6,10]$.

A. James і співавт. (2006) у лікуванні IM у вагітних також рекомендують використовувати коронарну ангіопластику, стентування та коронарне шунтування [4].

Наводимо клінічний випадок розвитку інфаркту міокарда у вагітної. Хвора Д., 1990 року народження, лікар-інтерн, вагітна (вагітність II, 8 тижнів). 28.12.2014 надійшла в ургентному порядку до відділення інвазивних методів діагностики і лікування (ІМДЛ) Центральної міської клінічної лікарні (ЦМКЛ) м. ІванаФранківська.

3 анамнезу хвороби відомо, що 28.12.14 p. близько $09^{00}$ хвора раптово відчула стискаючий, пекучий біль за грудниною, відчуття нестачі повітря, вкрилася холодним потом, звернулася по медичну допомогу в ургентну лікарню, де була оглянута терапевтом. 3 анамнезу життя: 12 років хворіє на цукровий діабет, інсулінозалежна, перша вагітність завершилася кесаревим розтином (2010), оперована 3 приводу катаракти (імплантовано штучний кришталик). У телефонному режимі повідомлено чергового кардіолога обласного клінічного кардіологічного диспансеру (ОККД), хвору госпіталізовано у відділення анестезіології з палатами інтенсивної терапії ОККд. Викликано на консультацію чергового кардіолога відділення ІМДЛ ЦМКЛ м. Івана-Франківська.

Об'єктивно: загальний стан тяжкий, шкіра бліда, волога, холодна (Forrester-IV). АТ 80/60 мм рт.ст., у легенях - ослаблене везикулярне дихання, у нижніх відділах вологі дрібноміхурцеві хрипи; тони серця ослаблені, ЧСС- 110 уд/хв, ритм правильний (симптом Killip IIA).

ЕКГ - ритм синусовий, правильний, елевація (3-4 мм) сегмента ST у I, II, aVL, $\mathrm{V}_{1}-\mathrm{V}_{3}$ - відведеннях, реципрокні зміни (депресія сегмента ST) у II, III aVF, V6 - відведеннях (рис. 1).

ЕхоКГ: фракція викиду - $50 \%$; гіпо,дискінезія передніх та передньосептальних сегментів базального та середнього відділів лівого шлуночка (парадоксальне розширення (вибухання) обмеженої ділянки міокарда в час систоли).

Рівень серцевого тропоніну I - 2,14 нг/мЛ $\left(28.12 .2014\right.$ о $\left.10^{30}\right)$.

У зв'язку з типовим больовим синдромом, наявністю на ЕКГ підйому сегмента ST, підвищення рівня серцевого тропоніну I, дискінезії передніх, передньо-септальних сегментів базального і середнього відділів ЛШ за даними трансторакальної ЕхоКГ, тривалість інтервалу «первинний медичний контакт- пристрій» 90 хв (I А клас доказовості) - ухвалено рішення про проведення ургентної коронарографії (КГ).

О $10^{30}$ ранку (після отримання письмової інформованої згоди на проведення черезшкірного коронарного втручання - ЧКВ) виконана КГ: правий тип кровопостачання серця; права коронарна артерія (ПКА) та огинаюча гілка лівої коронарної артерії (ОГ ЛКА) без гемодинамічно значимих звужень (ТIMI-3); 100 \% оклюзія на межі проксимального і серединного сегментів передньої міжшлуночкової гілки лівої коронарної артерії (ПМШГ ЛКА), ТІМІ-0 (рис. 2).

Проведене ургентне стентування ПМШГ ЛКА ВMS Integrity 3,5 х26,0 мм, ТІМІ-3 (рис. 3).

$\mathrm{ED}$ - 496,53 mGy, поточна доза плода 99,306 mGy, 19,9 рад.

Після проведеної ЧКВ повністю припинився біль за грудниною, на ЕКГ резолюція сегмента $\mathrm{ST}-80 \%$. Загальний стан задовільний, пульс регулярний - 96 уд/хв, тони серця ясні, частота дихання 17/хв.

Результати обстеження. Загальний аналіз крові (28.12.2014): Ле. - 13,510\%/л; ШОЕ - 10 мм/ год; лімф. $-22 \%$; мон. $-4 \%$.

Біохімічний аналіз крові (28.12.2014): білок - 58 г/л; сечовина - 3,1-ммоль/л; креатинін 57,8-80,0 мкмоль/л; глюкоза - 8,4 ммоль/л; $\mathrm{K}^{+}$ 


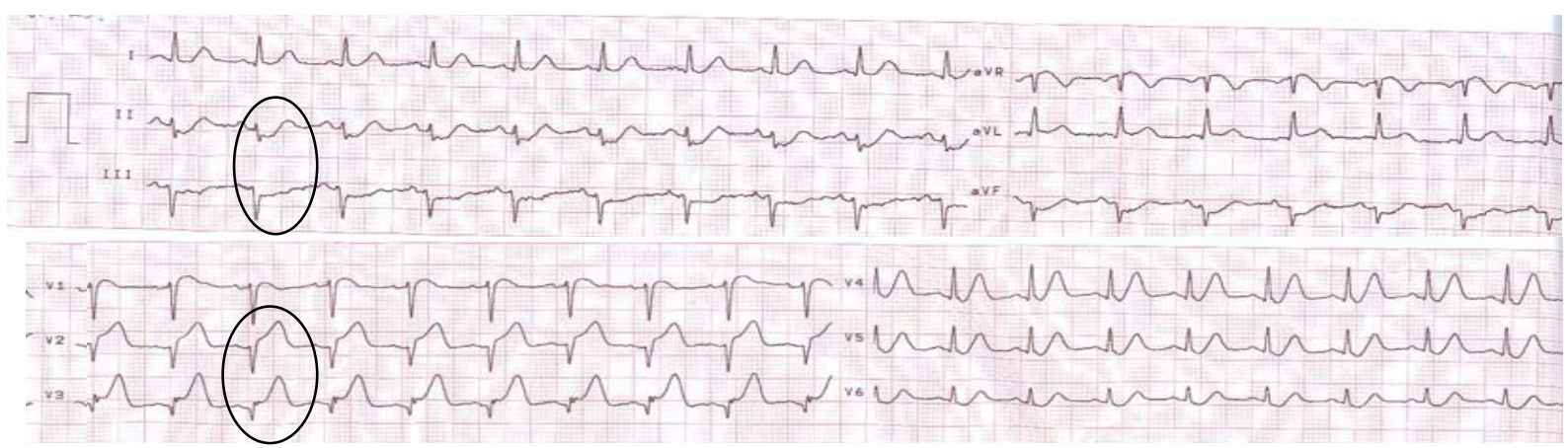

Рис. 1. Електрокардіограма хворої Д. при надходженні до стаціонару

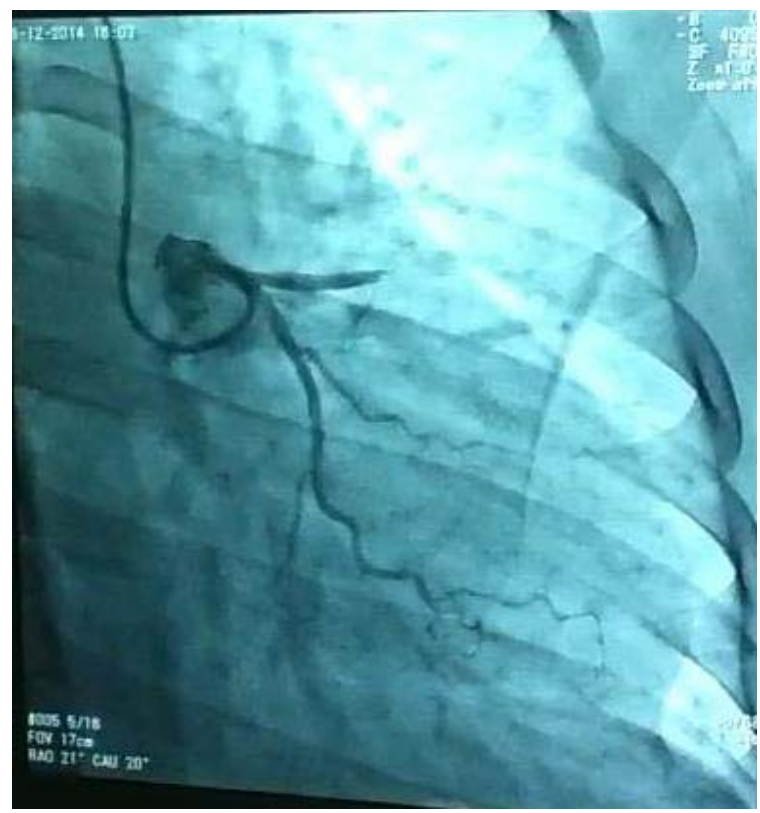

Рис. 2. Коронарографія хворої Д. до стентування

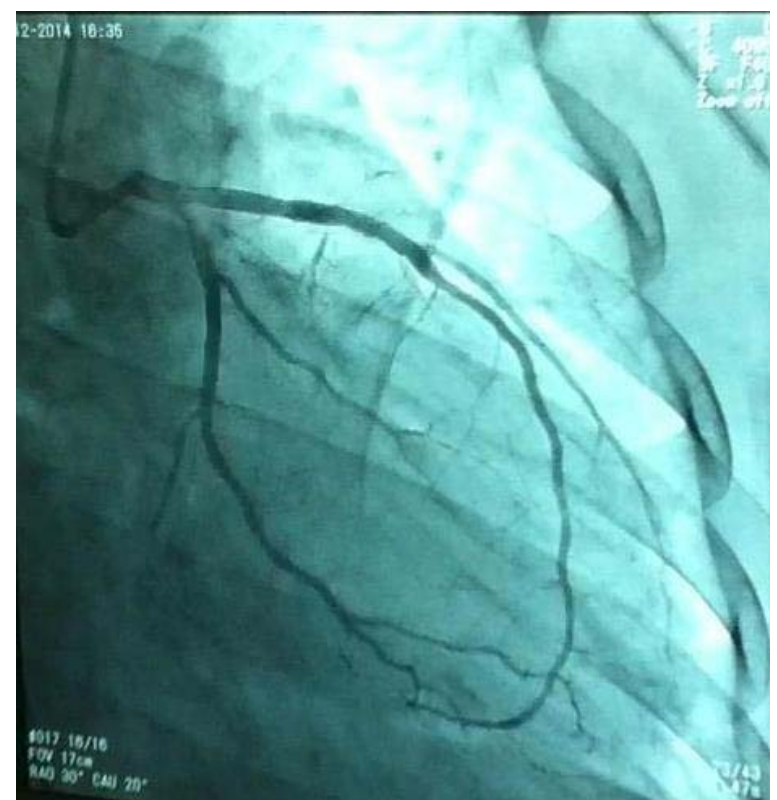

Рис. 3. Коронарографія хворої Д. після черезшкірного коронарного втручання

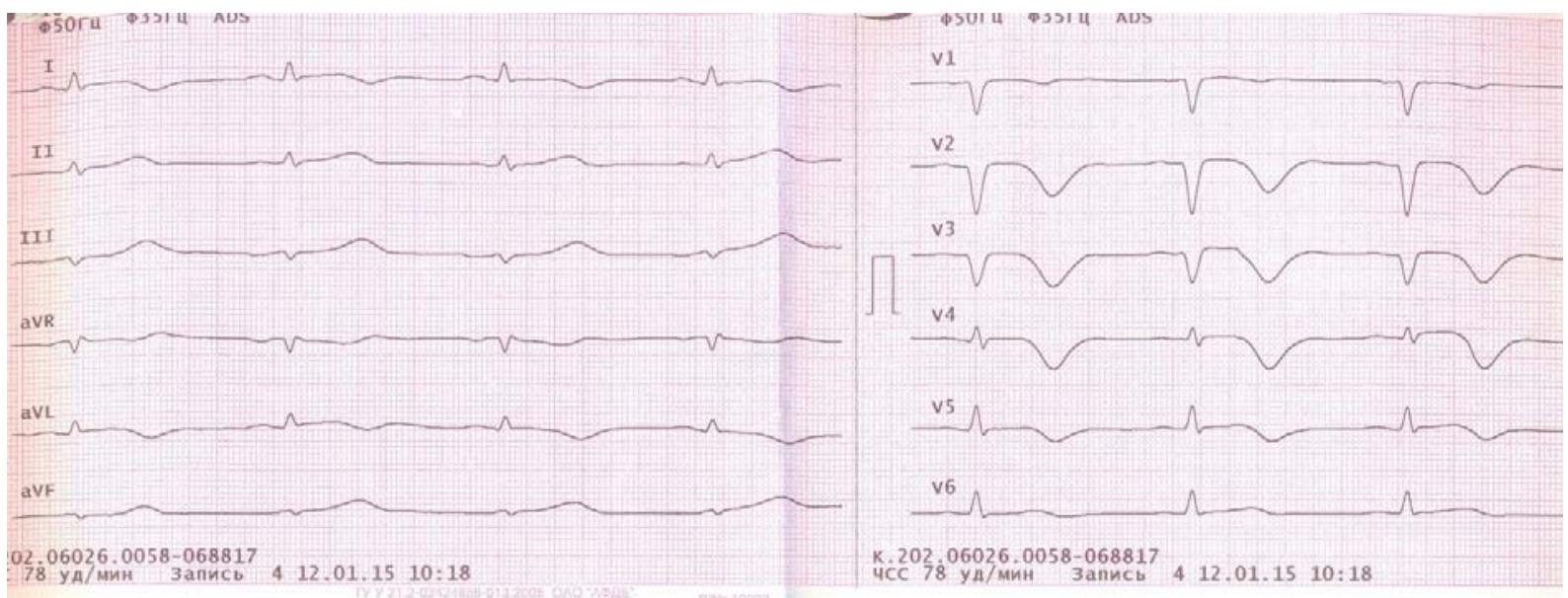

Рис. 4. Електрокардіограма хворої Д. на 15 -ту добу після інфаркту міокарда

4,16 ммоль/л; $\mathrm{Na}^{+}-142,3$ ммоль/л; $\mathrm{Ca}^{2+}-1,01$ ммоль/л; $\mathrm{CL}^{-}-107,5$ мкмоль/л.

Коагулограма (28.12.2014): міжнародне нормалізаційне співвідношення (INR) - 2,44 од; протромбіновий індекс - 53,7 \%; фібриноген 1,54 гл; АЧТЧ -270с.

Ліпідограма (29.12.2014): 3ХС - 5,0 ммоль/л; ТГ - 1,54 ммоль/л; ЛПНГ -3,17 ммоль/л; ЛПВГ 1,13 ммоль/л; ЛПДНГ - 0,7 ммоль/л; коефіцієнт атерогенності - 3,42 од.
ЕКГ (після ЧКВ, через 90 хв): резолюція сегмента ST $80 \%$.

УЗ - дослідження матки: у порожнині матки візуалізується плідне яйце діаметром 37 мм; плід 11 мм, серцебиття збережене; вагітність 7-8 тижнів.

Діагноз: IXC-гострий інфаркт міокарда 3 елевацією сегмента ST (ГIMе ST), локалізацією в передніх та передньо-септальних сегментах базальних і серединних відділів лівого шлуночка, ускладнений гострою лівошлуночковою недоста- 
тністю Killip IIA класу, Forrester IV (28.12.2014, $\left.9^{00}\right)$. Ургентна коронарографія: $100 \%$ оклюзія на межі проксимального і мідіального сегментів ПМШГ ЛКА, ТІМІ-0. Ургентне стентування ПМШГ ЛКА, ТІМІ -3 (28.12.2014).

Цукровий діабет-I тип, субкомпенсований, інсулінопотребуючий. Висновок: дисліпідемія IIA тип за Frederixon. Вагітність II, 7- 8 тижнів.

Рекомендації згідно з консультацією акушера-гінеколога: враховуючи категоричний протипоказ до вагітності, за даної патології доцільне переривання. Вагітна Д. не дала згоди на переривання вагітності і продовжувала її виношування.

Враховуючи зазначене вище, хворій Д. після стентування металевим стентом призначено: антидіабетичне харчування, збагачене овочами, фруктами, морепродуктами, поліненасиченими жирними кислотами, з обмеженням солі $(<7$ г/ добу); антитромбоцитарні засоби (аспірин - 75 мг/добу), антикоагулянти (еноксапарин упродовж перших чотирьох днів 1 мг/кг х2 р/д 3 переходом на ривароксабан у дозі 2,5 мг 2 р/д); антиішемічні засоби ( $\beta$-адреноблокатор бісопролол- 1,25 мг/ добу); триметазидин -140 мг/добу, у перші три дні, а відтак - 70 мг/добу; омакор - 1 г/добу; інсулінотерапія (згідно $з$ рекомендацією ендокринолога).

Вагітність і пологи у вагітної Д. завершилися 14.07.2015 р. о 9 год 40 хв 3 вилученням із матки шляхом кесаревого розтину доношеної дівчинки, масою 3620 г, довжиною $53 \mathrm{~cm}, 3$ оцінкою пологів у 7,7 бала за шкалою Апгара.

\section{Висновок}

Інфаркт міокарда у вагітних із супутнім цукровим діабетом є актуальною проблемою, оскільки є потенційно небезпечним коморбідним станом для вагітної і майбутньої дитини. Діагностика інфаркту міокарда у вагітних повинна базуватися на оцінці больового синдрому (типовий, атиповий, неангінальний), змін на електрокардіограмі (елевація сегмента ST понад 2 мм не менше, ніж двох суміжних грудних відведеннях), рівня серцевих тропонінів (I, T), ехокардіограми (зони гіпо-, акінезії, дискінезії).

\section{Література}

1. Ишемическая болезнь сердца и беременность (обзор литературы) / Н.Т. Ватутин. Г.Г. Тарадин, А.А. Тараторина [и др.] // Мед.-соц. пробл. сім'ї. - 2013. - Т. 18, № 4. - C. 97-106.

2. Инфаркт миокарда и инсульт при беременности О.Н. Ткачева, Н.В. Шарашкина, И.М. Новикова [и др.] // Здоров'я України. - 2010. - № 6 (235). C. $30-31$.

3. Ткачева О.Н. Инфаркт миокарда и беременность / О.Н. Ткачева, Н.В. Шарашкина // Пробл. жен. здоровья. -2008 . - Т. 3, № 3. - С. 25-30.

4. Acute myocardial infarction in pregnancy: a United States population based study / A. James, M. Jamison, M. Biswas [et al.] // Circulation. - 2006. - Vol. 113. P. 1564-1571.

5. Badui E. Acute myocardial infarction during pregnancy and puerperium: a review / E. Badui, R. Enciso // Angiology. - 1996. -Vol. 47. - P. 739-756.

6. Bowater S.E. Management of pregnancy in women with acquired and congenital heart disease / S.E. Bowater, S.A. Thorne // Postgrad. Med. J. - 2010. - Vol. 86. P. 100-105.

7. Hunter S. Adaptation of the maternal heart in pregnancy / S. Hunter, S. Robson // Brit. Heart J. - 1992. - Vol. 68. P. 540-543.

8. James A. Incidence and risk factors for stroke in pregnancy and the pu-erperium / A. James, C.D. Bushnell, M. Jamison // Obstet Gynecol. - 2005. - Vol. 106. P. 509-525.

9. Ladner H. Acute myocardial infarction in pregnancy and the puerpenum: a population-based study / H. Ladner, B. Danielsen, W. Gilbert // Obstet Gynecol. - 2005. Vol. 105 (3). - P. 480-484.

10. Leiserowitz G. Creatinekinase and its MB isoenzyme in the third trimester and the peripartum period / G. Leiserowitz, A. Evans, S. Samuels // J. Reprod. Med. - 1992. Vol. 37. - P. 910-916.

11. Peripartum myocardial ischemia: a review of Canadian deliveries from 1970 to 1998 / A. Macarthur, L. Cook, J.K. Pollard [et al.] // Am. J. Obstet. Gynecol. - 2006. Vol. 194 (4). - P. 1027-1033.

12. Pregnancy after acute coronary syndrome: a proposal for patients' management and a literature review / A. JanionSadowska, M. Sadowski, J. Kurzawski [et al.] // BioMed. Res.Intern. - 2013. - P. 1-7.

13. Roth A. Acute Myocardial Infarction Associated With Pregnancy / A. Roth, U. Elkayam // J. Am. Coll. Cardiol. - 2008. - Vol. 52. - P. 171-180.

14. Sciscione A. Acute Pulmonary Edema in Pregnancy A.Sciscione, T. Ivester // Obstetrics \& Gynecology. 2003. - № 101. - P. 511-515.

\section{ИНФАРКТ МИОКАРДА ПРИ БЕРЕМЕННОСТИ: СЛУЧАЙ ИЗ ПРАКТИКИ}

\section{Р.В. Денина}

Резюме. Сердечно-сосудистые заболевания по-прежнему остаются одной из главных причин материнской смертности в развитых странах. Наиболее распространенные проблемы, осложняющие беременность, это ожирение, нарушение липидного обмена, сахарный диабет, артериальная гипертензия, курения. Развитие инфаркта миокарда у беременных достаточно редкая ситуация. Однако в последние годы наблюдается значительное увеличение частоты факторов риска сердечно-сосудистых заболеваний у беременных, увеличивается возраст женщин, планирующих беременность. В статье представлен клинический случай из практики, а именно развитие инфаркта миокарда у беременной женщины с сопутствующим сахарным диабетом.

Ключевые слова: инфаркт миокарда, беременность, клинический случай, диагностика, лечение. 


\section{MYOCARDIAL INFARCTION AND PREGNANCY: A CLINICAL CASE}

\section{R.V. Denina}

Abstract. Cardiovascular diseases are still a major cause of maternal mortality in developed countries. The most common problems that complicate pregnancy are obesity, lipid metabolism, diabetes mellitus, arterial hypertension, smoking.

Myocardial infarction in a pregnant woman is quite rare today. However, in recent years there has been a significant frequency increase of risk factors for cardiovascular diseases in pregnant women, increasing age of women planning pregnancy. The article presents a clinical case, namely the myocardial infarction in a pregnant woman with concomitant diabetes mellitus.

Key words: myocardial infarction, pregnancy, clinical case, diagnosis, treatment.

SHEE "National Medical University" (Ivano-Frankivsk)

Рецензент - проф. В.К. Тащук

Buk. Med. Herald. - 2015. - Vol. 19, № 4 (76). - P. 253-257

Надійшла до редакції 14.09.2015 року

(C) Р.В. Деніна, 2015 